\section{JURNAL EKONOMI EFEKTIF}

ISSN : $2622-8882$, E-ISSN : 2622-9935

Jurnal Ekonomi Efektif, Vol. 3, No. 2, Januari 2021 @Prodi Manajemen Fakultas Ekonomi Universitas Pamulang

\title{
PENGARUH PELATIHAN KERJA DAN KEPUASAAN KERJA KARYAWAN TERHADAP PERFORMA KERJA KARYAWAN (STUDI KASUS PADA PT. GARUDA KARYA MANDIRI)
}

\author{
Eti Ariyanti ${ }^{1 *}$, Edy Krisyanto ${ }^{2}$ \\ Universitas Pamulang, Tangerang Selatan, Banten, Indonesia \\ dosen02302@unpam.ac.id**
}

Manuskrip: Sept-2020; Ditinjau: Okt-2020; Diterima: Nov-2020; Online: Jan-2021; Diterbitkan: Jan-2021

\begin{abstract}
ABSTRAK
Tujuan penelitian ini adalah untuk mengetahui pengaruh pelatihan kerja dan kepuasan kerja karyawan terhadap performa kerja karyawan di PT Garuda Karya Mandiri, Jakarata, secara simultan. Tujuan dari penelitian ini adalah untuk mengetahui pengaruh pelatihan dan kepuasan kerja terhadap performa karyawan PT. Garuda Karya Mandiri. Variabel bebas dalam penelitian ini adalah pelatihan (X1), kepuasan kerja (X2) dan performa kerja karyawan (Y) sebagai variabel terikat. Populasi dalam penelitian ini adalah karyawan PT GARUDA KARYA MANDIRI bagian Account Officer (AO). Teknik penarikan sampel menggunakan Sensus Sampling dengan sampel yang digunakan adalah 100 orang. Teknik analisis data yang digunakan adalah analisis regresi berganda untuk menguji hipotesis penelitian Hasil dari penelitian ini menunjukkan bahwa variabel pelatihan berpengaruh positif signifikan terhadap performa kerja karyawan dengan dan variabel kepuasan kerja berpengaruh positif signifikan terhadap performa kerja karyawan PT. Garuda Karya Mandiri.
\end{abstract}

\section{Kata Kunci: Kepuasan Kerja, Performa Kerja Karyawan.}

\section{ABSTRACT}

The aims of this research is to determine the effect of training and employee satisfaction to performance work in PT Garuda Karya Mandiri, Jakarta, simultaneously. The independent variable is training (X1), employee satisfaction (X2), and its depanden varibel is iPerformance work (Y). The population on this research is the employees in PT Garuda Karya Mandiri in Account Officer (AO) division. The sample taken by sensus sampling with 100 selected employees. Data analyses techniques applied on this research is multiple regretion in testing the hypothesis to show the variable significancy and the the independen variables show their positive significant to performance work in PT Garuda Karya Mandiri.

Keywords: Job Satisfaction, Employee Performance. 


\section{PENDAHULUAN}

\section{A. Latar Belakang Masalah}

Sumber daya manusia merupakan salah satu aset yang paling berharga, karena sumber daya manusia yang baik maka diharapkan mampu menjawab semua tantangan yang datang baik dari dalam maupun luar organisasi atau perusahaan untuk mencapai tujuan organisasi atau perusahaan. Kualitas sumber daya manusia yang dibutuhkan dapat terpenuhi dengan dilakukannya pengembangan yang mengarah kepada pelatihan yang merupakan upayaterutama untuk mengembangkan kemampuan intelektual sumber daya manusia dan kepribadian karyawan (Harmanto, 2005).

Dalam meningkatkan kualitas sumber daya manusisa, maka harus memiliki peran penting dalam meningkatkan daya saing organisasi, apabila suatu perusahaan memiliki sumber daya yang berkualitas maka perusahaan tersebut memiliki daya saing yang tinggi, sehingga akan lebih berperan dalam akselerasi pembangunan yang sedang giat diupayakan, maka untuk melakukan kualitas pegawai dapat dilakukan dengan mengadakan pelatihan yang dimaksudkan untuk meningkatkan keahlian, kemampuan dan keterampilan karyawan sehingga performa kerja karyawan akan meningkat dan karyawan akan merasakan kepuasan pada dirinya (Yendra, 2006).

Menurut Hamalik (2001:10) dalam Yamin (2005) pelatihan adalah suatu proses yang meliputi serangkaian tindakan atau upaya yang dilaksanakan dengan segala dalam bentuk pemberian bantuan kepada karyawan yang dilakukan tenaga profesional kepelatihan dalam satuan waktu yang bertujuan untuk meningkatkan kemampuan kerja peserta dalam bidang pekerjaan tertentu guna meningkatkan efektifitas dan produktivitas dalam suatu organisasi.

Pelaksanaan pelatihan dan pengembangan sumber daya manusia bagi karyawan banyak memberikan masukan positif yang berhubungan dengan kemauan dan kemampuan karyawan dalam menyelesaikan pekerjaanya, dan menggaeksistensi diri dan rasa percaya diri akan tumbuh dan terus berkembang, yang pada akhimya mampu mendorong performa kerja karyawan dan menunjukkan produktivitas kerja organisasi itu sendiri (Siagian, 1993: 187) dalam (Hermanto, 2005).

Faktor lain yang berpengaruh terhadap performa karyawan adalah kepuasan kerja. Luthans (1995) dalam Nurmalini (2008) menjelaskan kepuasan kerja adalah ungkapan kepuasan tentang bagaimana pekerjaan mereka dapat memberikan manfaat bagi organisasi. Sedangkan menurut Handoko (1997:193) dalam Sriwidodo (2007:37) menjelaskan kepuasan kerja adalah keadaan emosional yang menyenangkan atau tidak menyenangkan dengan mana karyawan memandang pekerjaan mereka. Sedangkan Luthans (1998:126) dalam Sriwidodo (2007:37) menyatakan bahwa kepuasan kerja adalah suatu keadaan emosi seseorang yang positif atau menyenangkan yang dihasilkan dari penilaian suatu pekerjaan atau pengalaman kerja. Apabila karyawan telah merasakan kepuasan dengan hasil kerja yang telah dilakukan maka mendapatkan imbalan dari perusahaan dan dapat meningkatkan performa kerja baik secara kuantitas dan kualitas yang dicapai oleh karyawan tersebut dalam menjalankan tugas dan tanggung jawab pekerjaannya (Syaiin, 2008).

Berdasarkan hasil observasi pendahuluan dengan membagikan kuesioner secara acak kepada seratus karyawan pada bagian penjualan yang bisa peneliti temui di kantor PT. Garuda Karya Mandiri, maka diperoleh jawaban bahwa sebagian besar karyawan merasa jarang sekali dapat menyelesaikan pekerjaan sesuai dengan yang ditargetkan dan waktu yang ditentukan. Karyawan juga kurang dapat memberikan gagasan-gagasan terbaiknya selama di perusahaan, meskipun aturan-aturan kerja yang diberlakukan 
perusahaan dipatuhi dengan baik oleh karyawan. Dapat disimpulkan bahwa rata-rata performa karyawan kurang baik, terutama karyawan pada bagian penjualan.

Selain itu, sebagian besar karyawan menyatakan kurang puas selama bekerja di PT. Garuda Karya Mandiri. Kondisi tersebut menyebabkan karyawan kurang termotivasi untuk mencapai target yang ditentukan oleh perusahaan. Karyawan juga merasa kurang puas atas peluang promosi, dimana sebagai penjual tidak memiliki peluang jabatan yang lebih tinggi. Dalam kaitan ini karyawan sangat berharap perusahaan tempatnya bekerja dapat memberikan masa depan yang lebih baik melalui promosi kerja yang tinggi, dimana pada bagian penjualan peluang untuk memperoleh jabatan lebih tinggi lebih sedikit bagi karyawan.

Aspek lainnya yang diduga menjadi faktor penting yang mempengaruhi penurunan performa karyawan di PT. Garuda Karya Mandiri adalah lingkungan kerja atau istilah lainnya suasana kerja, atau iklim kerja yang buruk. Hal ini karena kebanyakan karyawan dinilai terlalu mementingkan dirinya sendiri untuk mencapai target dibanding karyawan lainnya, sehingga menciptakan hubungan komunikasi dan interaksi diantara karyawan yang kurang harmonis.

Dalam Laporan Tahunan Berkelanjutan Tahun 2012 yang diterbitkan PT. Garuda Karya Mandiri, tenaga kerja adalah salah satu kunci utama kesuksesan usaha jasa penerbangan dalam menjalankan tugas yang tersebar di seluruh Indonesia. PT. Garuda Karya Mandiri mengelola segala urusan pegawai mulai dari perencanaan segala tahap pengembangan ketenagakerjaan atau mulai dari rekrutment, seleksi karyawan, pemetaan talent, pengembangan karir, dan suksesi hingga pegawai pensiun. PT. Garuda Karya Mandiri menggunakan Integrated Human Capital Management sebagai pedoman untuk mengelola sumber daya manusia.

Sementara itu dari sisi performa kepegawaian, berdasarkan Laporan Tahunan Berkelanjutan yang diterbitkan PT. Garuda Karya Mandiri pada tahun 2012, berdasarkan hasil Survey yang dilakukan oleh Louis Allen Worlwide Inc. memperlihatkan bahwa Employee Engagement Index (EEI) PT. Garuda Karya Mandiri pada tahun 2012 berada pada skor 4,2 yang sama dengan pencapaian tahun 2011 dan naik 0,18 point dari skor tahun 2010 . Tidak ada kenaikan skor yang signifikan pada Employee Engagement Index (EEI) PT. Garuda Karya Mandiri. Disisi lain dengan jangkauan skala 1-5, nilai tersebut menandakan bahwa para pegawai menikmati suasana kerja di PT.Garuda Karya Mandiri dan telah merasa terikat sebagai bagian tak terpisahkan dari perusahaan.

Tetapi, jika di telisik secara lebih fokus pada PT.Garuda Karya Mandiri terjadi penurunan performa karyawan. Berdasarkan laporan rangkuman peniliaan performa (job appraisal summary report) PT.Garuda Karya Mandiri pada tahun 2012. Diketahui bahwa terdapat penurunan performa karyawan sebesar $17 \%$ tahun 2012 dari $20 \%$ tahun 2011 pada skala peniliaian performa karyawan dalam penilaian 'baik' yang dijelaskan lebih terperinci melalui tabel di bawah ini :

Tabel 1

Job Appraisal Summary Report PT.Garuda Karya Mandiri Kantor Tahun 2011-2012

\begin{tabular}{|c|c|c|c|c|c|}
\hline $\begin{array}{c}\text { Penilaian } \\
\text { performa }\end{array}$ & skala & Tahun 2011 & Tahun 2012 & $\begin{array}{c}\text { Penilaian } \\
\text { performa }\end{array}$ & skala \\
\hline Baik & A & $\begin{array}{c}\text { Jumlah } \\
\text { karyawan }\end{array}$ & presentase & $\begin{array}{c}\text { Jumlah } \\
\text { karyawan }\end{array}$ & presentase \\
\hline Cukup baik & B & 73 & $20 \%$ & 17 & $17 \%$ \\
\hline Kurang baik & C & 7 & $7 \%$ & 74 & $74 \%$ \\
\hline
\end{tabular}




\begin{tabular}{|c|c|c|c|c|c|}
\hline Kurang & D & 0 & $0 \%$ & 0 & $0 \%$ \\
\hline Buruk & E & 0 & $0 \%$ & 0 & $0 \%$ \\
\hline TOTAL & & 100 & $100 \%$ & 100 & $100 \%$ \\
\hline
\end{tabular}

Berdasarkan tabel diatas diketahui bahwa terjadi penurunan performa karyawan yaitu terdapat penurunan performa karyawan antara tahun 2011 hingga tahun 2012. Pada tahun 2011 sebanyak 20 karyawan mendapatkan penilaian performa pada skala penilaian 'baik' pada skala penilaian (A) sedangkan pada tahun penurunan terjadi pada tahun 2012 sebanyak 17 karyawan yang mendapatkan penilaian performa pada skala penilianan 'baik' (A). sedangkan itu kenaikan juga terjadi pada jumlah karyawan dengan skala penilaian 'kurang baik', pada tahun 2011 jumlah karyawan pada skala penlianan 'kurang baik' (C) sebesar $7 \%$, jumlah tersebut meningkat pada tahun 2012 menjadi sebanyak $9 \%$. Hal ini menunjukan bahwa belum optimalnya performa karyawan penjabaran diatas, peneliti ingin mengetahui seperti apa posisi pengaruh masing-masing variabel yaitu program pelatihan dan kepuasan kerja karyawan atas reward, situasi dan kondisi kerja yang selama ini diciptakan PT.Garuda Karya Mandiri terhadap performa karyawan

\section{B. Rumusan Masalah}

1. Seberapa besar pelatihan kerja karyawan terhadap performa karyawan PT Garuda Karya Mandiri.

2. Seberapa besar kepuasaan karyawan terhadap performa kerja karyawan PT Garuda Karya Mandiri.

3. Seberapa besar pelatihan dan kepuasaan karyawan terhadap performa karyawan secara simultan

\section{Tujuan Penelitian}

1. Untuk menganalisis pengaruh pelatihan kerja terhadap performa karyawan

2. Untuk menganalisis pengaruh kepuasan karyawan terhadap performa karyawan.

3. Untuk menganalisis pengaruh kepuasan karyawan terhadap performa karyawan dengan kepuasan kerja sebagai variabel intervening yang memiliki hubungan langsung ataupun tidak langsung yang dapat diukur.

\section{METODE PENELITIAN}

\section{Populasi}

Populasi dalam penelitian ini adalah karyawan PT. Garuda Karya Mandiri Tbk. Kantor Jakarta Pusat yang saat ini berjumlah 100 karyawan

2. Sampel

Dalam penelitian ini sampel ditentukan secara probabilitas (probability sampling) dengan metode sampel acak sederhana (simple random sampling).

\section{Jenis Penelitian}

Jenis penelitian yang dipakai adalah asosiatif, dimana tujuannya adalah untuk mengetahui mencari keterhubungan antara variabel independen terhadap variabel dependennya

\section{Metode Analisis Data}

Dalam menganalisis data digunakan uji validitas, uji reliabilitas, analisis regresi linier sederhana, koefisien korelasi, koefisien determinasi dan uji hipotesis. 


\section{HASIL PENELITIAN DAN PEMBAHASAN}

\section{Uji Validitas data}

Tabel 2

Hasil Uji Validitas Variabel Program Pelatihan (X1)

\begin{tabular}{|c|c|c|c|}
\hline Pertanyaan & Pearson Correlation & Signifikansi & Keterangan \\
\hline Pertanyaan 1 & 0,859 & 0,000 & Valid \\
\hline Pertanyaan 2 & 0,847 & 0,000 & Valid \\
\hline Pertanyaan 3 & 0,781 & 0,000 & Valid \\
\hline Pertanyaan 4 & 0,767 & 0,000 & Valid \\
\hline Pertanyaan 5 & 0,838 & 0,000 & Valid \\
\hline Pertanyaan 6 & 0,832 & 0,000 & Valid \\
\hline Pertanyaan 7 & 0,859 & 0,000 & Valid \\
\hline Pertanyaan 8 & 0,570 & 0,000 & Valid \\
\hline
\end{tabular}

Berdasarkan tabel diatas dapat diketahui bahwa nilai rhitung atau Pearson Correlation yang didapat berdasarkan hasil uji validitas SPSS lebih besar dari pada rtabel sebesar 0,3301, hal menunjukan bahwa seluruh instrument dalam variable Pelatihan dinyatakan valid.

\section{Uji Validitas Variabel Kepuasan karyawan (X2)}

\section{Tabel 3}

Hasil Uji Validitas Variabel Kepuasan Karyawan (X2)

\begin{tabular}{|c|c|c|c|}
\hline Pertanyaan & Pearson Correlation & Signifikansi & Keterangan \\
\hline Pertanyaan 1 & 0,646 & 0,000 & Valid \\
\hline Pertanyaan 2 & 0,745 & 0,000 & Valid \\
\hline Pertanyaan 3 & 0,713 & 0,000 & Valid \\
\hline Pertanyaan 4 & 0,555 & 0,000 & Valid \\
\hline Pertanyaan 5 & 0,728 & 0,000 & Valid \\
\hline Pertanyaan 6 & 0,729 & 0,000 & Valid \\
\hline Pertanyaan 7 & 0,629 & 0,000 & Valid \\
\hline Pertanyaan 8 & 0,502 & 0,000 & Valid \\
\hline Pertanyaan 9 & 0,437 & 0,000 & Valid \\
\hline Pertanyaan 10 & 0,564 & 0,000 & Valid \\
\hline
\end{tabular}

Berdasarkan tabel diatas diketahui bahwa nilai rhitung atau Pearson Correlation yang didapat berdasarkan hasil uji validitas SPSS lebih besar dari pada rtabel sebesar 0,3301, hal menunjukan bahwa seluruh instrument dalam variabel Pelatihan dinyatakan valid.

\section{Uji Validitas Variabel Performa Karyawan (Y)}

Tabel 4

Hasil Uji Validitas Variabel Performa Karyawan (Y)

\begin{tabular}{|c|c|c|c|}
\hline Pertanyaan & Pearson Correlation & Signifikansi & Keterangan \\
\hline Pertanyaan 1 & 0,666 & 0,000 & Valid \\
\hline Pertanyaan 2 & 0,346 & 0,000 & Valid \\
\hline Pertanyaan 3 & 0,662 & 0,000 & Valid \\
\hline Pertanyaan 4 & 0,390 & 0,002 & Valid \\
\hline Pertanyaan 5 & 0,538 & 0,000 & Valid \\
\hline Pertanyaan 6 & 0,703 & 0,000 & Valid \\
\hline Pertanyaan 7 & 0,686 & 0,000 & Valid \\
\hline Pertanyaan 8 & 0,593 & 0,000 & Valid \\
\hline Pertanyaan 9 & 0,558 & 0,000 & Valid \\
\hline Pertanyaan 10 & 0,332 & 0,013 & Valid \\
\hline
\end{tabular}


Berdasarkan tabel 4 diatas diketahui bahwa nilai rhitung atau Pearson Correlation yang didapat berdasarkan hasil uji validitas SPSS lebih besar dari pada rtabel sebesar 0,3301, hal menunjukan bahwa seluruh instrument dalam variabel Pelatihan dinyatakan valid.

\section{Uji Reliabilitas}

Tabel 5

Uji Reliabilitas Variabel

\begin{tabular}{|c|c|c|}
\hline Variabel & Cronbach's alpha & Keterangan \\
\hline Program pelatihan & 0,911 & Reliabel \\
\hline Variable & Cronbach's alpha & Keterangan \\
\hline Kepuasan karyawan & 0,936 & Reliabel \\
\hline Performa karyawan & 0,743 & Reliabel \\
\hline
\end{tabular}

Berdasarkan tabel 5 diatas dikatehui bahwa semua variabel memiliki koefisiensi alpha diatas 0,6 sehingga dapat dikatakan bahwa semua konsep pengukur masing masing variabel dari masing masing kuisioner adalah reliable.

Tabel 6

Hasil Uji Korelasi Antar Variabel

\begin{tabular}{|l|l|l|l|l|}
\hline & & performa_Y & $\begin{array}{l}\text { Pelatihan } \\
\text { kerja x1 }\end{array}$ & $\begin{array}{l}\text { Kepuasan } \\
\text { karyawan } \\
\text { x2 }\end{array}$ \\
\hline Pearson & Performa_Y & 1.000 & .570 & .623 \\
\hline Correlation & Pelatihan_X1 & .570 & 1.000 & .226 \\
\hline & $\begin{array}{l}\text { Kepuasan_Karyawa } \\
\text { n_X2 }\end{array}$ & .623 & .226 & 1.000 \\
\hline Sig. (1-tailed) & performa_Y &. & .000 & .000 \\
\hline Pelatihan_X1 & .000 &. & .041 \\
\hline Kepuasan karyawan_X2 & .000 & .041 &. \\
\hline N & Performa_Y & 60 & 60 & 60 \\
\cline { 2 - 5 } & Pelatihan kerja_X1 & 60 & 60 & 60 \\
\cline { 2 - 4 } & $\begin{array}{l}\text { Kepuasan_kar } \\
\text { yawan_x2 }\end{array}$ & & 60 & 60 \\
\hline
\end{tabular}

Berdasarkan tabel diatas yang mengambarkan hasil uji korelasi antar variabel diketahui bahwa variabel pelatihan (X1) dan variabel kepuasan karyawan (X2) memiliki korelasi masing-masing 0,226 dan 1,000 terhadap variabel performa karyawan (Y). Sementara itu variabel pelatihan (X1) dan variabel kepuasan karyawan (X2) memiliki korelasi masing-masing 0,570 dan 0,623 terhadap variabel performa (Y).

Tabel 7

Tabel Koefisien Determinasi

\begin{tabular}{|c|c|c|c|c|c|c|c|c|c|}
\hline \multirow[b]{2}{*}{ Model } & \multirow[b]{2}{*}{$\mathrm{R}$} & \multirow[b]{2}{*}{$\begin{array}{l}\mathrm{R} \\
\text { Square }\end{array}$} & \multirow[b]{2}{*}{$\begin{array}{l}\text { Adjusted } \\
\text { R } \\
\text { Square }\end{array}$} & \multirow[b]{2}{*}{$\begin{array}{l}\text { Std. Error } \\
\text { of the } \\
\text { Estimate }\end{array}$} & \multicolumn{5}{|c|}{ Change Statistics } \\
\hline & & & & & $\begin{array}{l}\text { R } \\
\text { Square } \\
\text { Change }\end{array}$ & Fhange & df1 & df2 & $\begin{array}{l}\text { Sig. F } \\
\text { Change }\end{array}$ \\
\hline & $.785^{\mathrm{a}}$ & .616 & .596 & 1.781 & 616 & 29.968 & 3 & 56 & 000 \\
\hline
\end{tabular}

a. Predictors: (Constant), performa_Kerja_Y, Pelatihan_X1, Kepuasan_Karyawan_X2

b. Dependent Variable: Kinerja_Y 
Berdasarkan tabel menunjukan bahwa koefisien determinasi yang digunakan untuk melihat kemampuan variabel independen dalam menerangkan variabel dependen, dimana nilai RSquere sebesar 0,616 yang dapat diartikan bahwa variabel pelatihan, kepuasan kompensasi dan kepuasan kerja mampu mempengaruhi kinerja sebesar $61,6 \%$ sedangkan sisanya sebesar 38,4\% dapat dijelaskan oleh variabelvariabel lain yang tidak diteliti dalam penelitian ini

\section{Pengujian Hipotesis Secara Individual}

Untuk menguji pengaruh secara individual baik secara parsial maupun simultan antara Program Pelatihan, Kepuasan kompensasi, dan kepuasan kerja terhadap variabel dependent yaitu performa kerja karyawan, dapat mengunakan tabel Coefficients berdasarkan analisis Regresi dengan program SPSS, seperti pada gambaran tabel dibawah ini :

Tabel 8.

Tabel Coeffients berdasarkan uji regresi Coefficients $^{\mathrm{a}}$

\begin{tabular}{|c|c|c|c|c|c|c|}
\hline \multirow[b]{2}{*}{ Mode } & & \multicolumn{2}{|c|}{$\begin{array}{c}\text { Unstandardized } \\
\text { Coefficients }\end{array}$} & \multirow{2}{*}{$\begin{array}{l}\text { Standardized } \\
\text { Coefficients } \\
\text { Beta }\end{array}$} & \multirow[b]{2}{*}{$t$} & \multirow[b]{2}{*}{ Sig. } \\
\hline & & B & Std. Error & & & \\
\hline \multirow[t]{4}{*}{1} & (Constant) & 15.391 & 2.621 & & 5.873 & .000 \\
\hline & Pelatihan_X1 & .307 & .068 & .398 & 4.509 & .000 \\
\hline & Kepuasan_Kompensasi_X2 & .143 & .057 & .315 & 2.501 & .015 \\
\hline & Kepuasan_Kerja_YY & .207 & .093 & 290 & 2.219 & .031 \\
\hline
\end{tabular}

variable performa kerja karyawan.

a. Program Pelatihan (X1) Berpengaruh Secara Signifikan Terhadap performa kerja Karyawan (Y) Uji secara individual ditunjukan oleh Coefficients. 40,1\%

b. Koefisien Jalur, Pengaruh Langsung dan Tidak Langsung, Pengaruh Total dan Bersama Variabel Pelatihan kerja (X1) dan Kepuasan Karyawan (X2) Terhadap performa kerja karyawan (Y):

\section{PENUTUP}

\section{Kesimpulan}

a. Berdasarkan indikator penelitian, responden dan analisa data penelitian, pada struktur model-1 dapat disimpulkan bahwa secara simultan variabel pelatihan kerja dan kepuasan karyawan PT. Garuda Karya Mandiri berpengaruh secara positif dan signifikan terhadap performa kerja karyawan.

b. Berdasarkan indikator penelitian, responden dan analisa data penelitian, pada struktur model-1 dapat disimpulkan bahwa secara parsial variabel pelatihan dan kepuasan karyawan masing-masing berpengaruh secara positif dan signifikan terhadap performa kerja karyawan PT. Garuda Karya Mandiri.

c. Pada struktur model-2 Berdasarkan indikator penelitian, responden dan analisa data penelitian dapat disimpulkan bahwa secara simultan variabel pelatihan dan kepuasan karyawan berpengaruh secara positif dan signifikan terhadap performa kerja karyawan PT. Garuda Karya Mandiri.

d. Pada struktur model-2 Berdasarkan indikator penelitian, responden dan analisa data 
penelitian dapat disimpulkan bahwa secara parsial masing-masing variabel pelatihan kerja dan kepuasan karyawan berpengaruh secara positif dan signifikan terhadap performa kerja karyawan PT.Garuda Karya Mandiri.

\section{Saran}

a. Pengaruh variabel pelatihan kerja dan kepuasan karyawan masih menjadi hal yang tidak terlalu berpengaruh terhadap performa kerja karyawan sehingga perlu dikaji kembali indikator dalam menilai performa kerja karyawan atas pelatihan kerja yang diikutinya sehingga secara lebih luas memberikan gambaran dan saran yang bermanfaat bagi perusahaan dalam mengadakan pelatihan yang faktanya bahwa perlu biaya yang besar untuk mengadakan pelatihan.

b. Dalam penelitian ini terdapat kelemahan dalam hal distribusi responden berdasarkan lama bekerja, diketahui masih terdapat kebiasaan dalam mengelompokan responden berdasarkan lama bekerja yang dapat menimbulkan makna ganda bagi pembaca. Diharapkan dalam penelitian selanjutnya, dapat diperbaiki dan disempurnakan kembali untuk mengidentifikasikan responden berdasarkan lama bekerja.

\section{DAFTAR PUSTAKA}

Akbar, I. R., \& Wiguna, M. (2020). Hubungan Motivasi Terhadap Prestasi Kerja Guru Pada SMK YAPIA Parung, Kab. Bogor. JENIUS (Jurnal Ilmiah Manajemen Sumber Daya Manusia), 4(1), 61-69.

Bruce, David A., 1991. The Effect of Training on Employee Job Satisfaction, Indiana: Ball State University.

Cheng, J. Lang, 2012. Examining The Implementation of Six Sigma Training and its Relationship with Job Satisfaction and Employee Morale, Asian Journal on Quality, Vol. 113, Hal. 100-110.

Choudhury, Dibyendu dan Mishra, Sasmita, Compensation-Satisfaction Correlation at Workplace: A Study on BPO at Orissa, International Journal of Business and Management Tomorrow, Vol. 1, No. 1.

Dessler, Gery, 2011. A Framework for Human Resource Management, NewJersey: Pearson Education Inc.

Dessler, Gery, 2011. Human Resource Management, New Jersey : Pearson Education Inc.

Greenberg, Jarald. dan Baron, Robert A., 1993. Behavior in Organizations, Jakarta: New York: Allyn and Bacon.

Idrus, Muhammad, 2009. Metodologi Penelitian ilmu Sosial Pendekatan Kualitatif dan Kuantitatif, Jakarta: Penerbit Erlangga.

Jogiyanto, 2008. Metodologi Penelitian Sistem Informasi : Pedoman dan Contoh Melakukan Penelitian di Bidang Sistem Tekhnologi Informasi, Yogyakarta: Andi Yogyakarta.

Kreitner, Robert dan Kinicki, Angelo, 2007. Organizational Behavior, New York: McGraw-Hill Companies Inc.

Mahesa, Deewar, 2010. Analisis Pengaruh Motivasi dan Kepuasan Kerja terhadap Kinerja Karyawan sebagai Variabel Modereting (Studi Kasus pada PT. Coca Cola Amatil Indonesia), Semarang: Universitas Diponegoro.

Mangkunegara, Prabu A, 2006. Perencanaan dan Pengembangan SDM, Bandung: Penerbit PT. Refika Aditama.

Martocchio, J. Joseph, 2008 : Employe Benefits, New York: McGraw-Hill Companies Inc. 
Mathis, R.L. dan Jackson J.H., 2008. Human Resource Management, United States of America: Tomson Learning Academic Resource Center.

Mathis, R.L. dan Jackson J.H., 2006. Human Resource Management, Jakarta: Salemba Empat.

Mathis, R.L. dan Jackson J.H., 2008. Human Resource Management : Essential Prespectives, United States of America: Cengage Learning.

Mondy, R.W., 2008. Manajemen Sumber Daya Manusia, Jakarta: Penerbit Erlangga.

Noe, Raymond, 2005. Employee Training and Developent, New York: McGraw- Hill Companies Inc.

Novianto, Djatmiko, 2009. Analisis PEngaruh Pelatihan dan Pengembangan, serta Kompensasi terhadap Kinerja Karyawan Pegawai Pada PT. Perusahaan Perkebunan London Sumatra Indonesia Tbk. Medan, Medan: Universitas Sumatra Utara.

Nugraha, Adhian, 2010. Analisis Pengaruh Ketidak Amanan Kerja dan Kepuasan Kompensasi terhadap Kinerja Karyawan (Studi Kasus pada Karyawan KOntrak PT. Bank Rakyat Indonesia Cabang Semarang Patimura dan Unit Kerjanya), Semarang: Universitas Diponegoro.

Olivia, Patricia, 2004. Hubungan di antara Kepuasan Kerja, Kepuasan Imbalan, Kepuasan Keadilan Imbalan dan Kepuasan Hidup pada Karyawan, Depok: Universitas Indonesia.

Ridwan dan Kuncoro, Engkos A., 2011. Cara Menggunakan dan Memakai Path Analysis (Analisis Jalur), Bandung: Alfabeta.

Rozi, A., \& Sunarsi, D. (2020). The Influence of Motivation and Work Experience on Employee Performance at PT. Yamaha Saka Motor in South Tangerang. Jurnal Office, 5(2), 65-74

Sarwani, S., Akbar, I. R., Handoko, A. L., \& Ilham, D. (2020). Pengaruh Pelatihan dan Motivasi terhadap Produktivitas Kerja Karyawan pada PT. Lion Mentari Airlines Bandara Internasional Soekarno Hatta Cengkareng. Jurnal Ilmu Komputer dan Bisnis, 11(2a), 91-100.

Sharman, Jai P. dan Bajpai, Naval, 2011. Salary Satisfaction as an Antecedent of Job Satisfaction: Development of a Regression Model to Determine the Linearity between Salary Satisfaction and Job Satisfaction in a Public and a Private Organization, European Journal of Social Sciences, Vol 18, Number 3, Hal 450 461.

Siswandoko, Darsono T., 2011. Manajemen Sumber Daya Manusia Abad 21, Jakarta: Nusantara Consulting.

Sunarsi, D. (2018). Pengaruh rekrutmen, seleksi dan pelatihan terhadap produktivitas kerja karyawan. KREATIF: Jurnal Ilmiah Prodi Manajemen Universitas Pamulang, 6(1), 14-31.

Suryoadi, Yerry, 2012. Pengaruh Pelatihan dan Kepuasan Kompensasi terhadap Kinerja Karyawan pada PT. Bank Muamalat Indonesia Cabang Semarang, Semarang: Universitas Diponegoro.

Sutrisno, S., \& Sunarsi, D. (2019). The Effect of Work Motivation and Discipline on Employee Productivity at PT. Anugerah Agung in Jakarta. Jurnal Ad'ministrare, 6(2), 187-196. 